\title{
Coordinated Power Management for Variable Speed Diesel Generator and Lithium-ion Battery Hybrid System
}

\author{
Gireesh Kumar A*, C A Babu \\ Division of Electrical Engineering, Cochin University of Science and Technology, Kochi, Kerala, India
}

Received August 26, 2019; Revised December 20, 2019; Accepted December 24, 2019

Copyright $@ 2019$ by authors, all rights reserved. Authors agree that this article remains permanently open access under the terms of the Creative Commons Attribution License 4.0 International License

\begin{abstract}
This paper presents coordinated operation of power management strategies for a hybrid system. This hybrid system is modeled based on dynamic variation of load power and its effective distribution strategy. The proposed hybrid system consists of variable speed diesel generator (VSDG) and lithium-ion battery which is able to supply electric power for Power, Water and Communication (PWC) economically and efficiently in rural areas. The variation of power demand in PWC load is highlighted in load profile. The total PWC load is effectively shared by two VSDGs and one Lithium-Ion battery bank. The use of advanced VSDG helps hybrid system to reduce fuel consumption as its speed varies with load demand. The proposed segmentation of high frequency and low frequency components of load currents and their assignation to suitable source helps to reduce the transients during load variations. Also, one of the generators will be switched off when the total power demand goes below specified level and hence significant fuel savings can be achieved. The execution of proposed system is assessed through MATLAB/Simulink model and its validation by experimental test bench.
\end{abstract}

Keywords AC/DC Converter, DC/DC Converter, Lithium-ion Battery, Loads Sharing Approach, Variable-speed Diesel Generator

\section{Introduction}

The main concern of people living in rural areas in all over globe about the power requirement for their essential needs like Power, Water and Communications [1]. The proposed hybrid model mainly aims to address the power supply for PWC system. The system consists of two variable speed diesel generators and one advance lithium-ion battery. Conventionally for reliable power supply, the constant speed diesel generator (CSDG) is most popular. The main issue of this conventional system is that it will run at constant speed irrespective of load variations. As it runs at constant speed in all different loads, the CSDG will consume fixed amount of fuel irrespective of load variations. The VSDG is designed to run at low speed and speed is adjusted with different loads through exciter control. A comparative study of VSDG and CSDG is narrated in [2]-[4]. The transients during sudden changes of loads are major concern in the operation of DGs. In order to avoid this kind of issues, a controlled Energy Storage System (ESS) along with CSDGs is explained in [5] and [6].

In this study, the hybrid operation executed with two VSDGs and one Lithium-ion battery are connected to a common dc bus. The proposed dc bus configuration helps to reduce the number of power switches and complexity of control [7]. A linearized model of power converters [8] and [9] (AC/DC and DC/DC) are adopted for various power conversion level of hybrid system. A similar hybrid diesel/battery propulsion system is described in [10] and [11]. For more extensive cases, multi-source hybrid systems (Diesel/Wind/Battery) are narrated in [12].

In this paper, a rural area power profile (PWC system) is designed with 500KVA load. Two VSDGs are connected to the dc bus through AC/DC converter and lithium-ion battery through a DC/DC converter shown in Figure.1. The power management is executed in such a way that the principal part of load is supplied by two VSDGs and keeps the voltage of dc bus in desired level.

In addition for supplying power to PWC system, the main concern of this paper is concentrated on the power mitigation of power fluctuations due to transients during load variations with help of energy storage system. Secondly, one of the VSDG is tured off when the total power demand goes below specified level and hence the fuel efficeincy can be improved. 


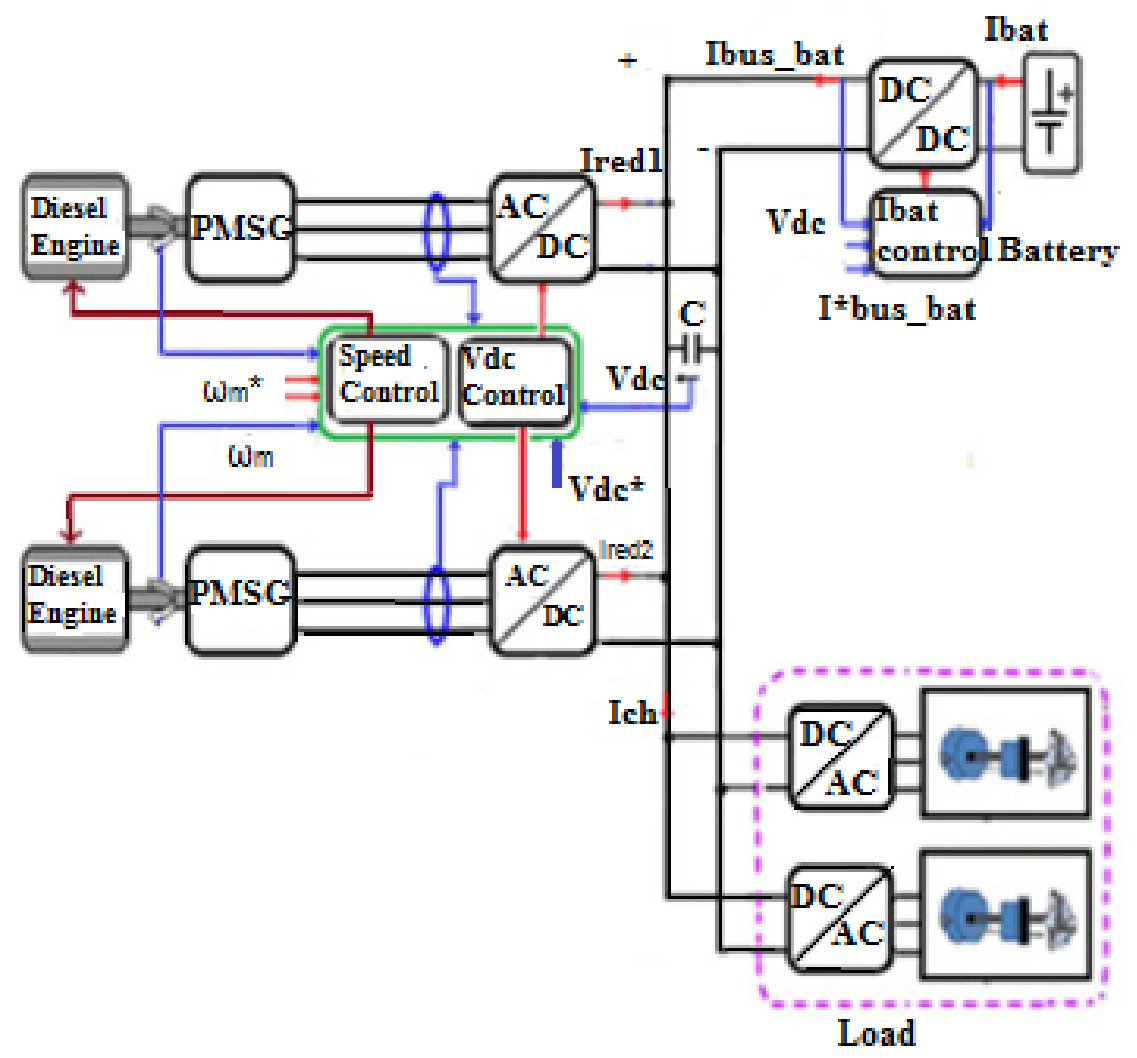

Figure 1. Configuration of hybrid system

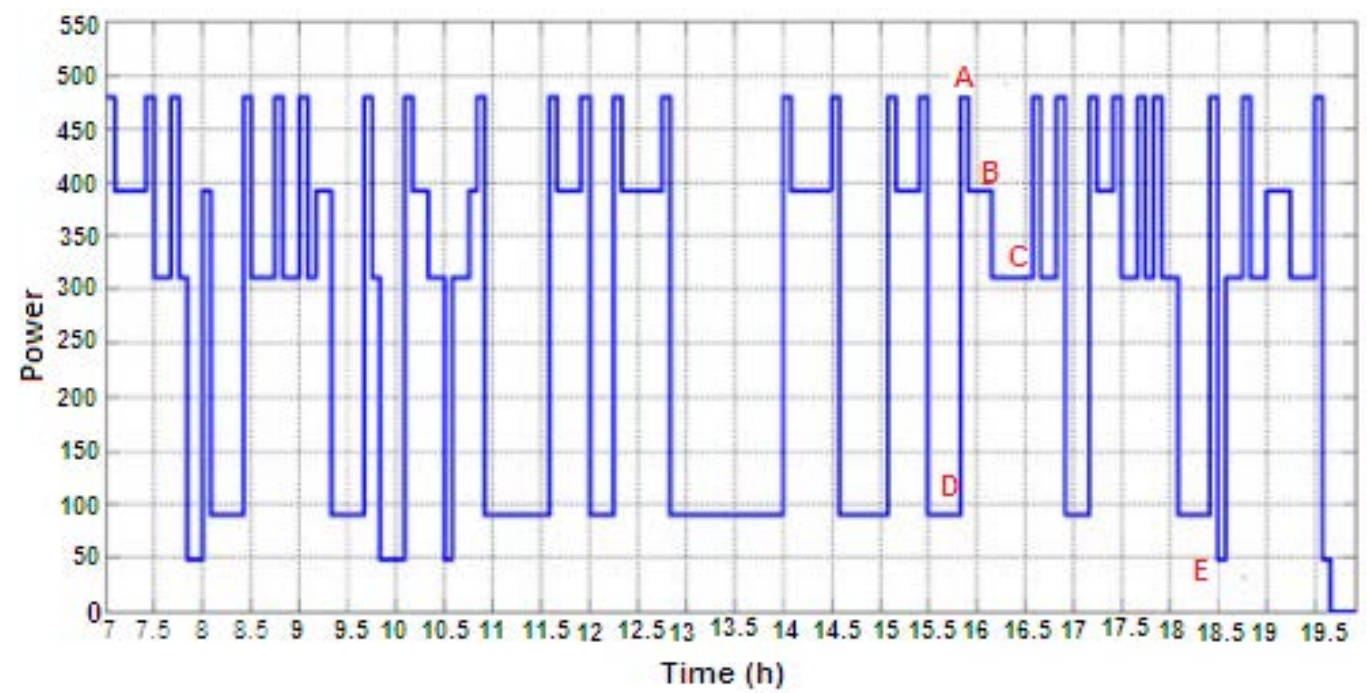

Figure 2. Load profile for the PWC system.

\section{Power Supply for PWC System}

A PWC system with $500 \mathrm{KVA}$ is considered for this study and daily operating duration from 7.00 am to 19.30 pm. Figure.2 shows PWC system power consumption profile with five levels. Level A (479 KVA, $450 \mathrm{KW}$ ) is the maximum power consumption, which consists of lighting load, water treatment plant and communication loads. Level B (391KVA, 365KW) relates to substantially reduced power level than level A. Accordingly, Level C (312 KVA, $288 \mathrm{KW}$ ), Level D (90 KVA, $77 \mathrm{KW)} \mathrm{and}$ Level E (50 KVA and $48 \mathrm{KW}$ ) are designed.

In this study, two identical VSDGs with 250 KVA capacity are considered as main power source. In order to reduce the transients during switching of loads, a lithium-ion battery is integrated. The power and energy variation of PWC load profile is shown in Figure.3. From the power curve, the maximum capacity required for 
battery system is determined by the relation $\Delta \mathrm{P}=\mathrm{P}_{\mathrm{VSDG}}{ }^{-}$ $\mathrm{P}_{\text {Load. }}$. From the energy curve, it is observed that maximum variation of energy, $\Delta \mathrm{E}_{\max }=44 \mathrm{kWh}$. This means that, the capacity of battery to be used is fixed at $44 \mathrm{kWh}$. But the $75 \%$ of total power of battery is usable, $60 \mathrm{kWh}$ rated battery is considered for this study.

A comparison of various battery technologies in terms of specific power, energy density and cost is given in Table 1. It is clear that even though the initial cost of lithium-ion battery is high, it has high energy density and long life. The mentioned advantages of lithium-ion battery ensure moderate operating cost and good working performance in the utilization period.

Table 1. Comparison of ESS technologies

\begin{tabular}{cccccc}
\hline Battery & $\begin{array}{c}\text { Specific Power } \\
(\mathrm{w} / \mathrm{kg})\end{array}$ & $\begin{array}{c}\text { Specific Energy } \\
(\mathrm{Wh} / \mathrm{kg})\end{array}$ & $\begin{array}{c}\text { Energy Density } \\
(\mathrm{Wh} / \mathrm{L})\end{array}$ & $\begin{array}{c}\text { Cycling Life } \\
(\text { cycles })\end{array}$ & $\begin{array}{c}\text { Capital Cost } \\
(\$ / \mathrm{kWh})\end{array}$ \\
\hline Lead-acid & 180 & 40 & 70 & 1000 & 300 \\
\hline $\mathrm{NiCd}$ & 230 & 65 & 100 & 2500 & 1150 \\
\hline $\mathrm{NaS}$ & 190 & 190 & 200 & 3000 & 450 \\
\hline $\mathrm{VRB}$ & 160 & 30 & 33 & 712000 & 600 \\
\hline $\mathrm{ZnBr}$ & 70 & 50 & 60 & 2000 & 500 \\
\hline Li-ion & 500 & 150 & 300 & 10000 & 2000 \\
\hline Flywheel & 950 & 50 & 50 & $>20000$ & 5000 \\
\hline
\end{tabular}
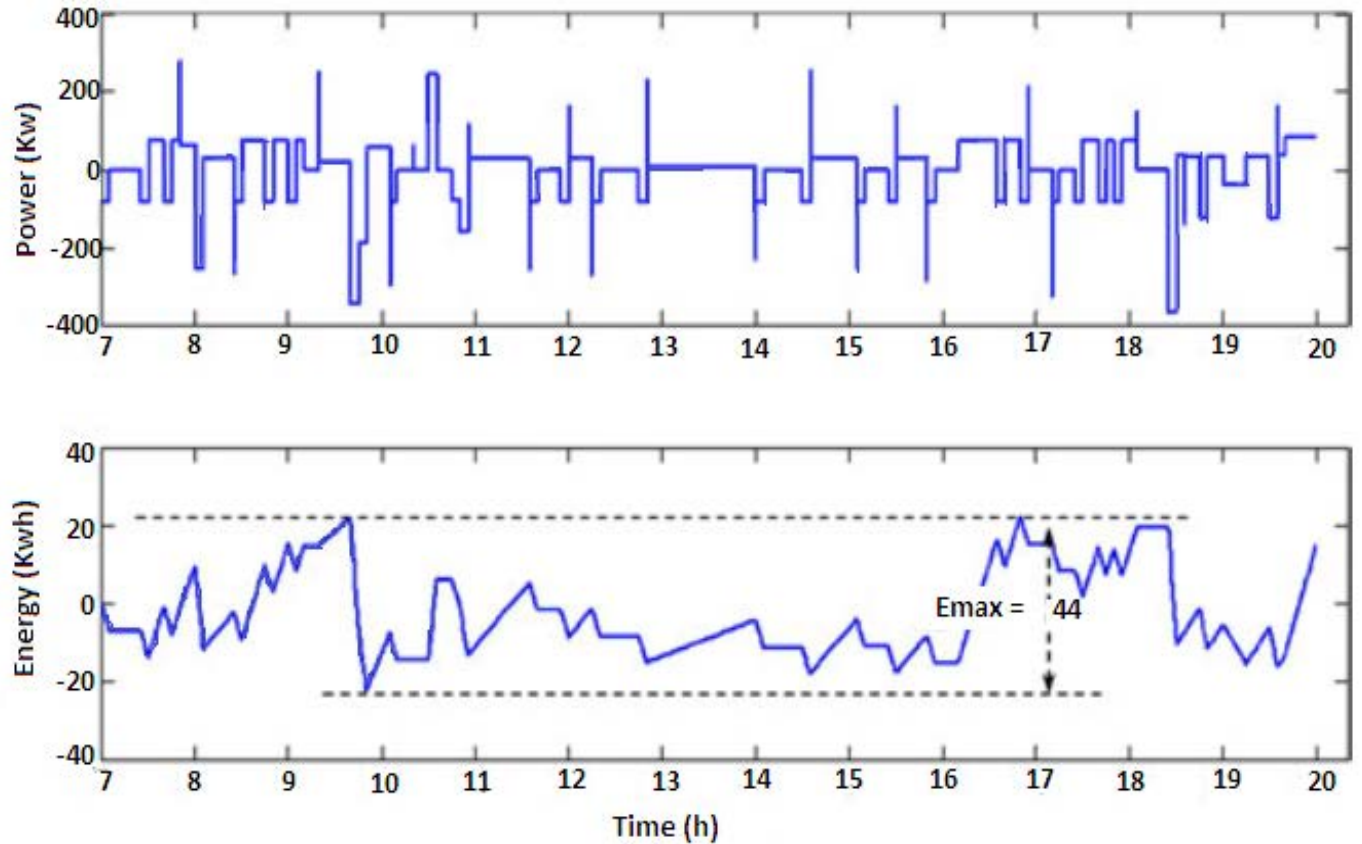

Figure 3. Power and energy variations for Energy storage system 


\section{Modeling of Subsystem}

\subsection{Variable Speed Diesel Generator (VSDG)}

The performance evaluation and complex control of conventional CSDG are depicted in [3] and [4]. The designing of VSDG includes the variation of speed according to fluctuating load that is executed by controlling the engine gain and ignition delay. The VSDG torque model in equation 1 is used from the reference [15] and [16].

$$
\begin{aligned}
& t_{m}=\left(\frac{1}{1+\tau_{2} \times s}\right) \times f\left(m_{f}\right) \times e^{-\tau_{1} \times s} \\
& f\left(m_{f}\right)=d_{3} \times m_{f}^{3}+d_{2} \times m_{f}^{2}+d_{1} \times m_{f}+d_{0} \\
& \tau_{1}=\frac{60 \times S_{t}}{2 \times N \times n_{c y 1}}+\frac{60}{4 \times N}
\end{aligned}
$$

Where $\tau_{\mathrm{m}}$ denotes engine mechanical torque, $\tau_{2}$ is time constant of actuator, $\mathrm{m}_{\mathrm{f}}$ is the fuel index. Here $S t$ is set as 4 for a four stroke engine, $\mathrm{n}_{\mathrm{cy} 1}$ denotes cylinder number and $N$ is the speed of the engine. The torque fits coefficients $d_{1}$; $\mathrm{d}_{2}$ and $\mathrm{d}_{3}$ are taken from [17]. The basic dynamic model of VSDG is derived from torque equation of Permanent Magnet Synchronous Generator (PMSG) [18]. Here Tm and $\mathrm{Te}$ are mechanical and electromechanical torques respectively and $J$ is the moment of inertia.

\subsection{Lithium-ion Battery Model}

The electrical modeling of lithium-ion battery is given in equation 3 from the literatures [19]-[21]. Where, $V_{\text {bat }}$ represents the voltage of battery and $\mathrm{I}_{\mathrm{bat}}$ current through battery. $N_{s}$ and $N_{p}$ are the number of series-parallel cells, open circuit voltage is denoted by Voc, $R_{E}$ and $R_{\Omega}$ show polarization and series resistances and $\mathrm{Cc}$ represents capacitance of battery cell.

$$
\left.\begin{array}{l}
V_{d}=R_{s} \times I_{d}+L_{d} \times \frac{d}{d t}\left(I_{d}\right)-\omega_{e} \times L_{q} \times I_{q} \\
V_{q}=R_{s} \times I_{q}+L_{q} \times \frac{d}{d t}\left(I_{q}\right)+\omega_{e} \times L_{d} \times I_{d}+\omega_{e} \times \psi_{m} \\
T_{e}=\frac{3}{2} \times p \times\left[\psi_{m}+\left(L_{d}-L_{q}\right) \times I_{d}\right] \times I_{q}
\end{array}\right\}
$$

\subsection{Converter Modeling}

A buck boost DC/DC converter is used in the battery side to condition the battery current that is shown in Figure.4. The average model of buck-boost converter is given in equation 3 and 4 . Where, for buck operation $k$ is set for -1 and for boost operation $k$ is set for 1 .

$$
\begin{aligned}
& V_{b a t}=N_{s} \times V_{o c} \times S o C-\frac{N_{s}}{N_{p}} \times Z_{e q} \times I_{b a t} \\
& \tau=C_{c} \times R_{c} \\
& Z_{e q}=R_{\Omega}+\frac{R_{c}}{1+\tau \times s} \\
& V_{\text {odsog }}=10^{-6} \times S O C-0.0002 \times S o C^{2}+0.013 \times S O C+3.5455 \\
& V_{\text {Lbat }}=L_{b a t} \times \frac{d}{d t}\left(I_{b a t}\right)=k\left(V_{b a t}-\alpha \times V_{a k}\right) \\
& V_{\text {Lbat }}=L_{b a t} \times \frac{d}{d t}\left(I_{b a t}\right)=k\left(V_{b a t}-\alpha \times V_{d c}\right) \\
& V_{d c} \stackrel{\substack{\text { Ibus_bat } \\
\longrightarrow}}{\stackrel{c}{\longrightarrow}}
\end{aligned}
$$

Figure 4. DC/DC Converter at battery side.

Equation 5 shows the relationship from bus current through battery ( $\mathrm{I}_{\text {bus-bat }}$ ) and battery generated current $\left(\mathrm{I}_{\text {bat }}\right)$.

$$
I_{b u s-b a t} \approx \frac{I_{b a t} \times V_{b a t}}{V_{d c}}
$$

The VSDG is connected to the dc bus through a AC/DC rectifier circuit and its average model is shown in 6 . Where, two VSDG currents are denoted by $\mathrm{I}_{\text {red1 } 1}$ and $\mathrm{I}_{\text {red2 } 2}$. The $\mathrm{I}_{\mathrm{ch}}$ denotes load current, $\mathrm{I}_{\mathrm{s} 1}, \mathrm{I}_{\mathrm{s} 2}, \mathrm{I}_{\mathrm{s} 3}$ represents stator current of $V_{S D G}$ and $I_{\mathrm{sp} 1}, I_{\mathrm{sp} 2} ; I_{\mathrm{sp} 3}$ represents stator current of $\mathrm{VSDG}_{2}$. The reference signal from pulse width modulation (PWM) circuit is shown as $\mathrm{S}_{\mathrm{a}}, \mathrm{S}_{\mathrm{b}}$ and $\mathrm{S}_{\mathrm{c}}$. The modification of DG output through a rectifier is depicted in [23]. The PWM control ensures the operating schedule of two VSDGs.

When total power demand is high, two VSDGs are equally sharing the load and when the demand goes below specified level, one of the VSDGs is turned off.

$$
\begin{aligned}
& \left(\begin{array}{l}
I_{\text {red } 1} \\
I_{\text {red } 2}
\end{array}\right)=S_{a} \times\left(\begin{array}{l}
I_{s 1} \\
I_{s 1 p}
\end{array}\right)+S_{b} \times\left(\begin{array}{l}
I_{s 2} \\
I_{s 2 p}
\end{array}\right)+S_{c} \times\left(\begin{array}{l}
I_{s 3} \\
I_{s 3 p}
\end{array}\right) \\
& C \times \frac{d}{d t}\left(V_{d c}\right)=I_{r e d 1}+I_{r e d 2}-I_{b u s-b a t}-I_{c h}
\end{aligned}
$$




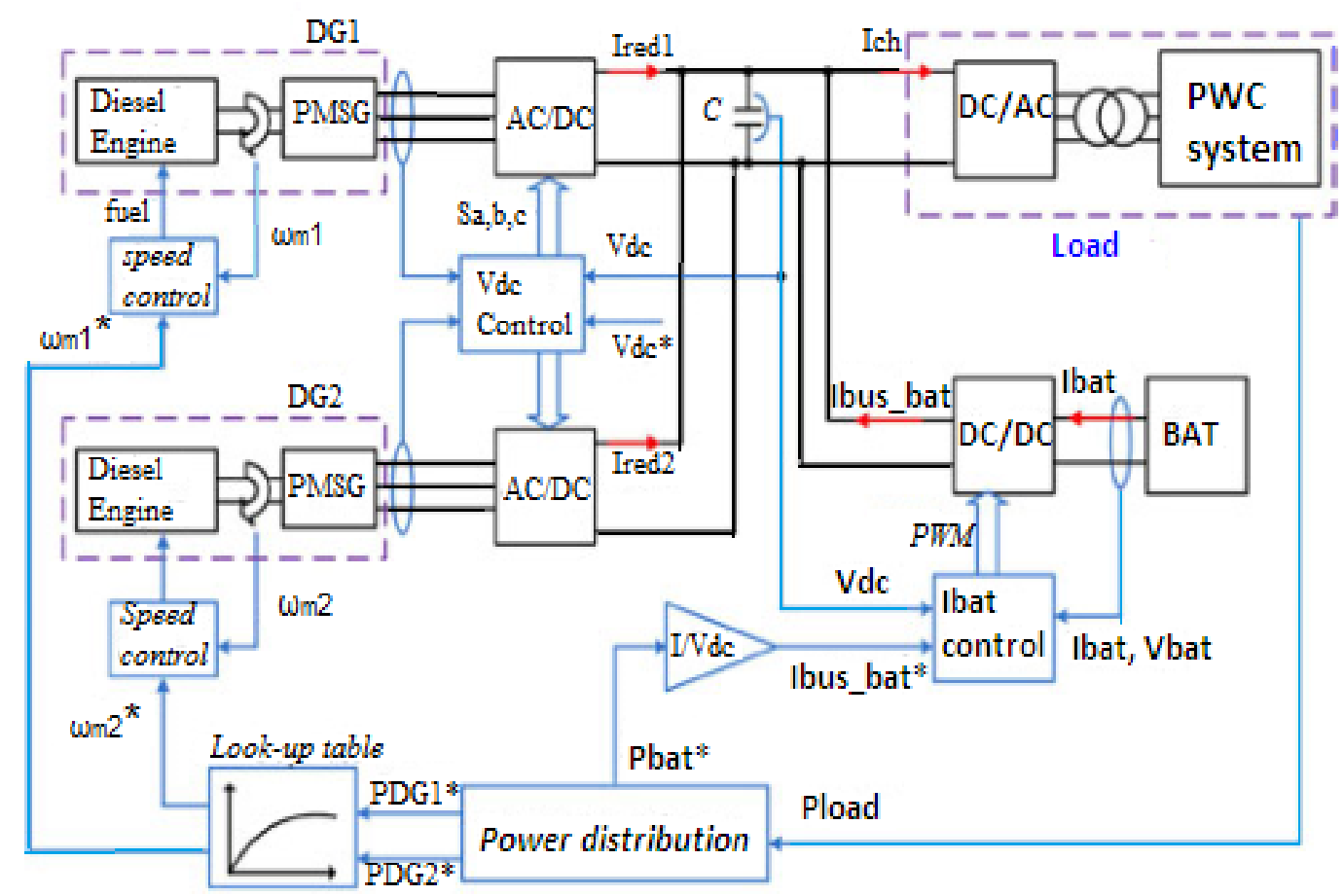

Figure 5. Power management and control schema for the PWC system.

\section{PWC System Power Management and Control}

The main aim of system power management is to divide the load current into high frequency segment and low frequency segment. The high frequency segment of load current is supplied by battery and low frequency segment is supplied from two VSDGs. The splitting of load current is carried out with help of low pass filter (LPF) and is shown in Figure.5.

In order to obtain the satisfactory performance of VSDGs, it must be operated over $35 \%$ of its rated capacity [24], [26]. In this study, two VSDGs of capacity $250 \mathrm{KVA}$, $200 \mathrm{~kW}$ each are used, hence $35 \%$ of $400 \mathrm{~kW}(140 \mathrm{~kW}=$ $400 \mathrm{~kW} \times 35 \%$ ) is set as operating limit of one VSDG.

$$
\left.\begin{array}{l}
\left(\begin{array}{c}
P_{D G 1}^{*} \\
P_{D G 2}^{*}
\end{array}\right)=\left(\begin{array}{l}
1 \\
0
\end{array}\right) \times P_{D G}^{*} \text { when } P_{D G}^{*}<140 \mathrm{~kW} \\
\left(\begin{array}{c}
P_{D G 1}^{*} \\
P_{D G 2}^{*}
\end{array}\right)=\left(\begin{array}{c}
0.5 \\
0.5
\end{array}\right) \times P_{D G}^{*} \text { when } P_{D G}^{*} \geq 140 \mathrm{~kW}
\end{array}\right\}
$$

\section{Simulation Results and Discussions}

In order to get satisfactory performance, the dc bus voltage is set for $1000 \mathrm{~V}$. In the simulation results, $I_{c h}$ represents load currents, the currents from $\mathrm{VSDG}_{1}$ and $\mathrm{VSDG}_{2}$ are indicated by $\mathrm{I}_{\text {red1 }}$ and $\mathrm{I}_{\text {red2 }}$ respectively. The battery current fed in to dc bus through a DC/DC converter is shown by $\mathrm{I}_{\text {bus-bat }}$. The proposed system and its control model are implemented in MATLAB/Simulink and it is validated by reducing scale test bench.

The load current $I_{c h}$ is shown in Figure.6 and the regulated dc bus voltage appears in Figure.7. The 10\% variation observed in dc bus voltage is due to transients during switching of loads. The battery current ( $\left.\mathrm{I}_{\text {bus-bat }}\right)$ fed in to dc bus is shown in Figure.8. The total current from two VSDGs $\left(\mathrm{I}_{\text {red1 }}+\mathrm{I}_{\text {red2 }}\right)$ is depicted in Figure 9. By observing Figure.8 and Figure.9, it is clear that the high frequency segment of load current is supplied from battery and low frequency segment from two VSDGs. 




Figure 6. Load current

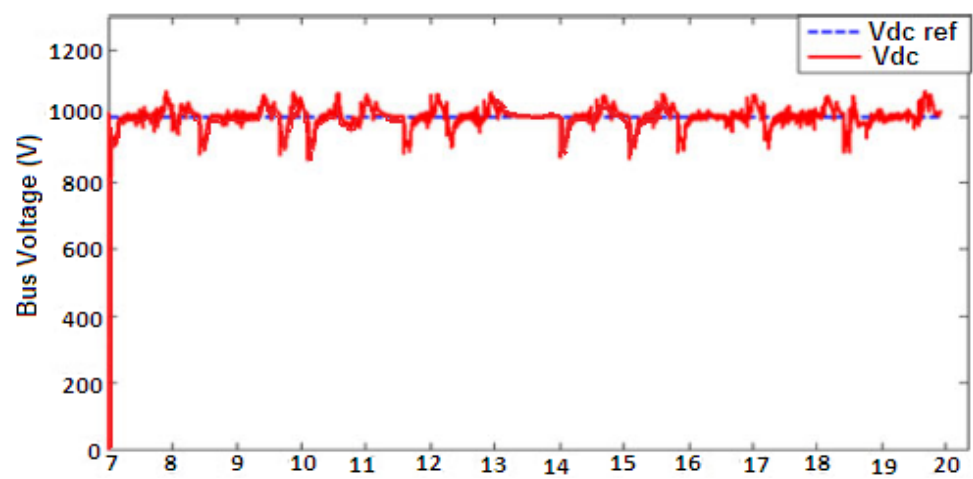

Figure 7. Regulated DC bus voltage

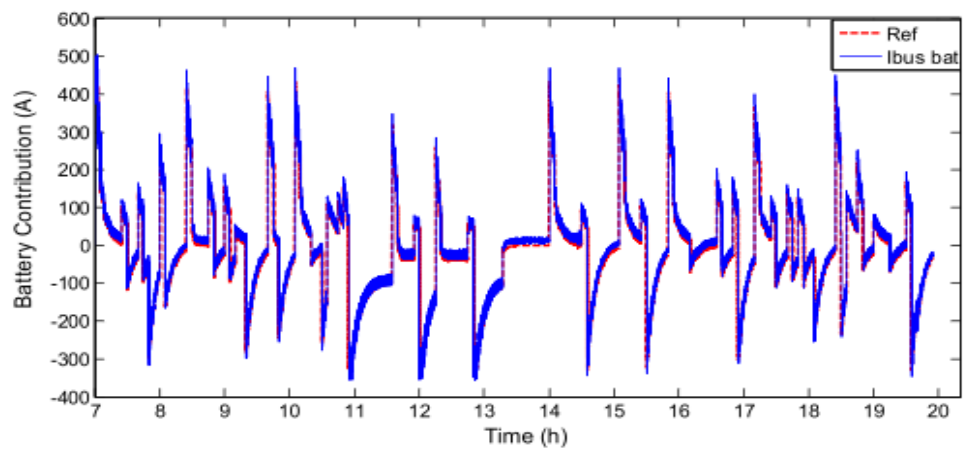

Figure 8. Lithium-ion battery current

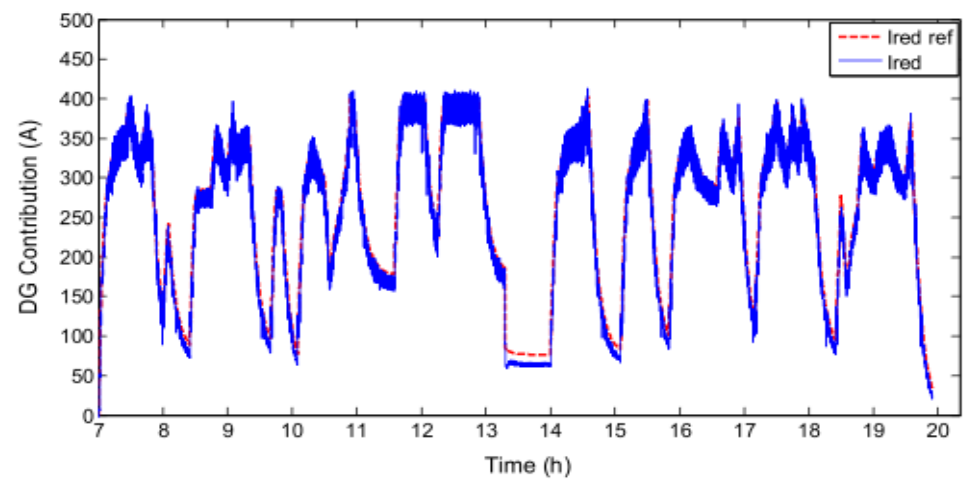

Figure 9. Total VSDG currents 
The current and voltage measured from battery side are given in Figure.10 and Figure.11. $\mathrm{I}_{\mathrm{bat}}$ has indistinguishable shape as $\mathrm{I}_{\text {bus-bat }}$. It is observed that when there is extensive rise in load current, the battery current diminishes (discharging) and when load current drops, battery current increases (charging). The current from two VSDGs is shown in Figure.12. The corresponding speed response is delineated in Figure.13. When load current is high, two VSDGs are equally sharing the power. When load current drops below $140 \mathrm{~kW}, \mathrm{VSDG}_{2}$ is turned off and $\mathrm{VSDG}_{1}$ alone supplies power.

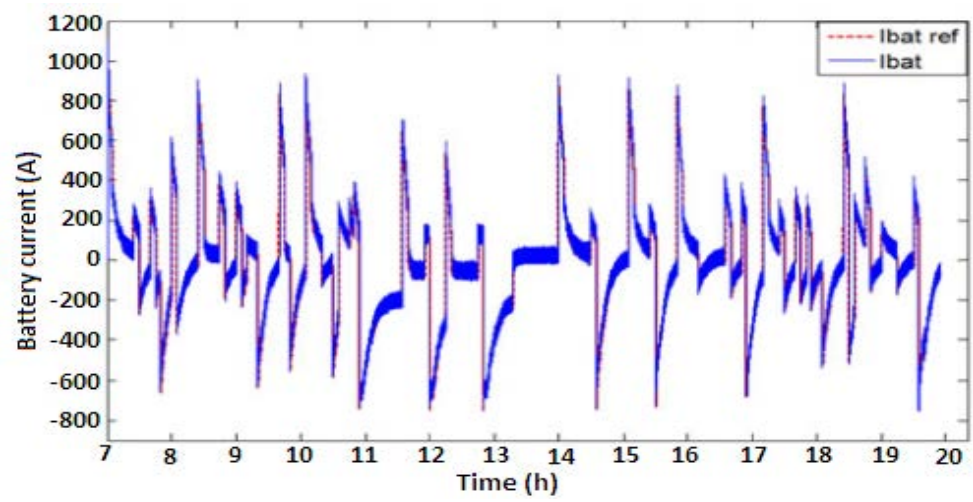

Figure 10. Current from battery.



Figure 11. Terminal voltage of battery.
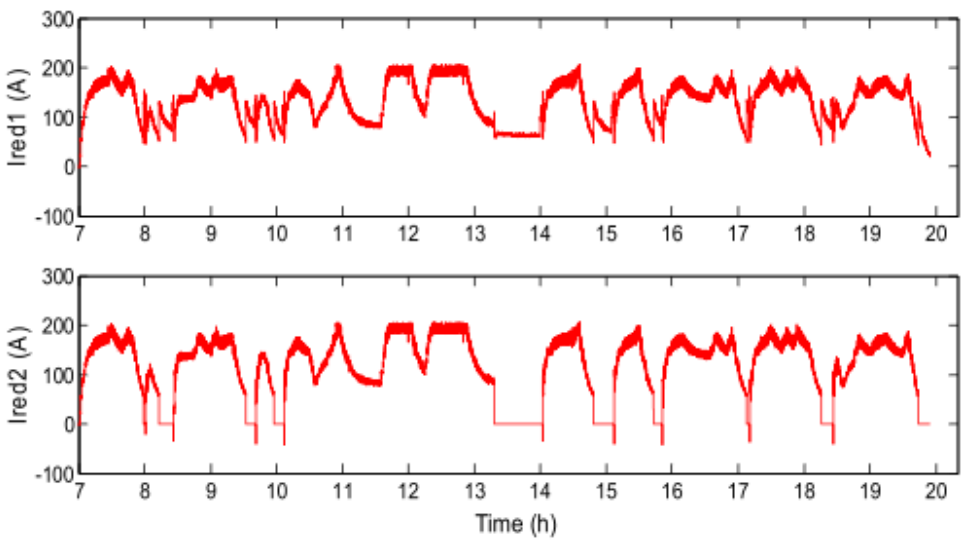

Figure 12. Current from $\mathrm{VSDG}_{1}$ and $\mathrm{VSDG}_{2}$. 




Figure 13. Speed variations of the $\mathrm{VSDG}_{1}$ and $\mathrm{VSDG}_{2}$.

\section{Experimental Validation}

A reduced scale experimental test bench is set up in our laboratory shown in Figure.14. The two voltage controlled dc sources are used to emulate $\mathrm{VSDG}_{1}$ and $\mathrm{VSDG}_{2}$ characteristics. A miniature programmable electronic load is used to asses PWC load profile. A 12V, 100 Ah lithium-ion battery connected to the dc bus through DC/DC buck-boost converter. The reference voltage for dc bus is set as $12 \mathrm{~V}$ and a scale factor 500 reduction obtained in load power. The control algorithm is executed by PIC18F4431 Microcontroller. By observing the experimental results it is clear that the simulation results are in consistent with experimental results.

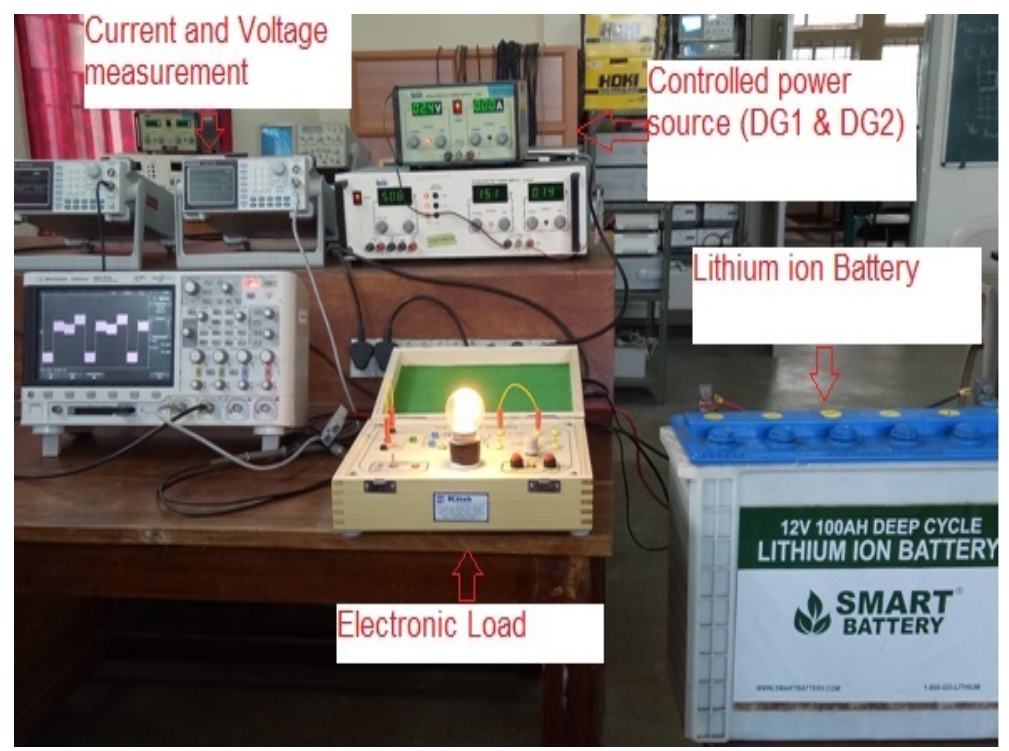

Figure 14. Experimental test bench 


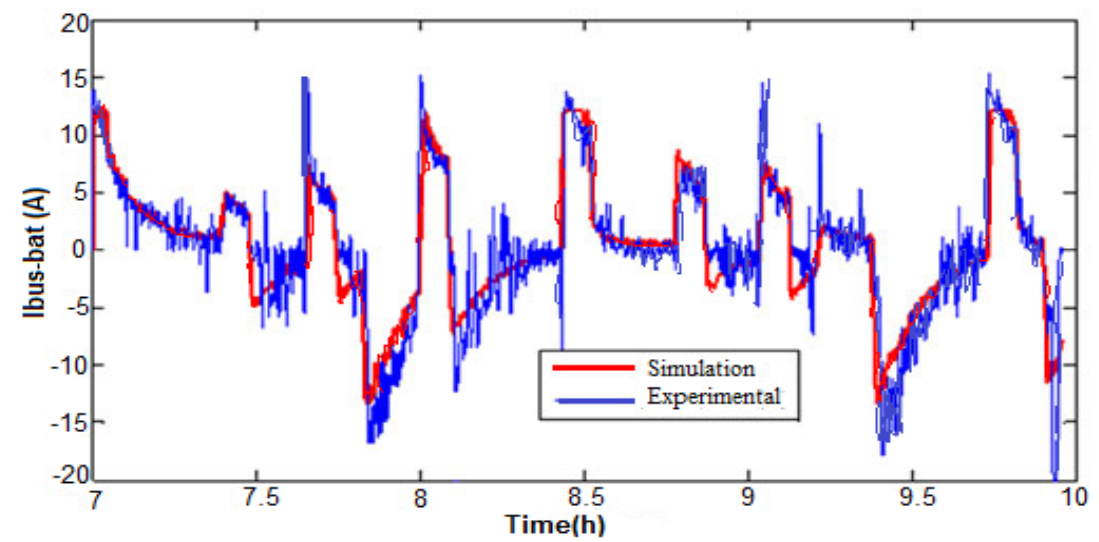

Figure 15. Lithium-ion battery current

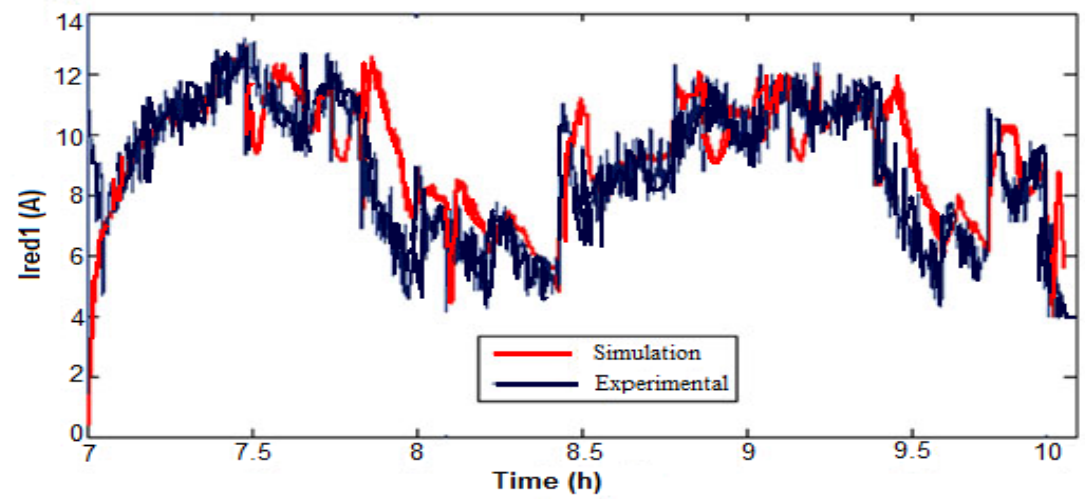

Figure 16. Current from $\mathrm{VSDG}_{1}$

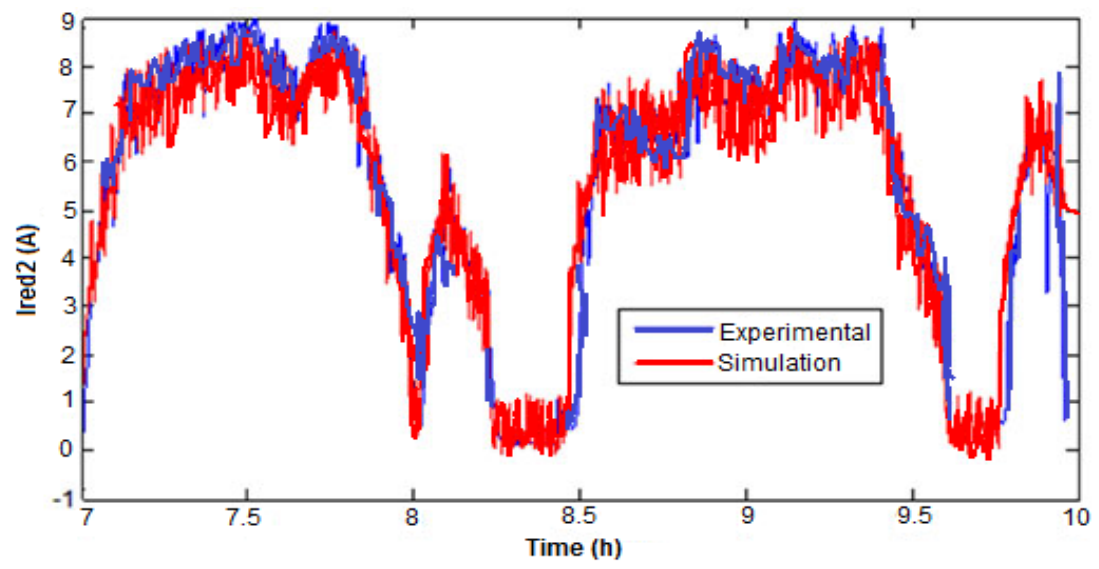

Figure 17. Current from $\mathrm{VSDG}_{2}$ 




Figure 18. Regulated dc bus voltage

\section{Conclusions}

This paper displays efficient and economic hybrid power generation system for rural area power, water and communication (PWC) applications. The frequency segmentation approach for load current ensures assignation of high frequency segment to lithium-ion battery and low frequency segment to two VSDGs, which reduce the transients during load variations. The simulation results confirm that during variation of speed and load current, the dc bus voltage is maintained constant. Additionally, when the load falls below specified level, one of the VSDGs is turned off and hence significant fuel savings can be achieved. The experimental test confirms the simulated results are in consistent with experimental results.

\section{REFERENCES}

[1] Arriaga, M., C.A. Cañizares, and M. Kazerani, Renewable Energy Alternatives for Remote Communities in Northern Ontario, Canada. IEEE Transactions on Sustainable Energy, 2013.

[2] K. Bellache, M. B. Camara, and B. Dakyo, "Hybrid electric boat based on variable speed diesel generator and lithium-battery-Using frequency approach for energy management,” in Proc. Int. Aegean Conf. Elect. Mach. Power Electron. (ACEMP), pp. 744-749, Sep. 2015.

[3] A. Lidozzi, L. Solero, and F. Crescimbini, “Adaptive direct-tuning control for variable-speed diesel-electric generating units,” IEEE Trans. Ind. Electron., vol. 59, no. 5, pp. 2126-2134, May 2012.

[4] J.-H. Lee, S.-H. Lee, and S.-K. Sul, "Variable-speed engine generator with supercapacitor: Isolated power generation system and fuel efficiency," IEEE Trans. Ind. Appl., vol. 45, no. 6, pp. 2130-2135, Nov./Dec. 2009.

[5] J. P. F. Trovao, V. D. N. Santos, C. H. Antunes, P. G. Pereirinha, and H. M. Jorge, "A real-time energy management architecture for multisource electric vehicles,"
IEEE Trans. Ind. Electron., vol. 62, no. 5, pp. 3223- 3233, May 2015

[6] Suliman Abdalla , Marwa Mekki , Osman Abdallah, Ahmed Ibrahim, "Charge Sharing Suppression in Single Photon Processing Pixel Array” Indonesian Journal of Electrical Engineering and Informatics (IJEEI) Vol. 5, No. 1, pp. 30-36, March 2017.

[7] K. Bellache, M. B. Camara, Z. Zhou, and B. Dakyo, "Energy management in hybrid electric boat based on frequency approach - using diesel, lithiumbattery and supercapacitors," in Proc. IEEE Veh. Power Propulsion Conf., Montreal, QC, Canada, pp. 1-6, Oct. 2015.

[8] J.M.Apsley et al., "Propulsion drive models for full electric marine propulsion systems,” IEEE Trans. Ind. Appl., vol. 45, no. 2, pp. 676-684, Mar./Apr. 2009

[9] B. Zahedi and L. E. Norum, "Modeling and simulation of all-electric ships with low-voltage DC hybrid power systems,” IEEE Trans. Power Electron., vol. 28, no. 10, pp. 4525-4537, Oct. 2013.

[10] S. Bolognani, A. Faggion, and L. Sgarbossa, "Power flow management design for an electric propulsion system of a hybrid catamaran,” in Proc. IEEE Power Electron. Appl., pp. 1-9 Aug. 2011.

[11] M. Bianucci, S. Merlino, M. Ferrando, and L. Baruzzo, "The optimal hybrid/electric ferry for the Liguria natural parks," in Proc. IEEE OCEANS-Genova, pp. 1-10, May 2015.

[12] M. A. Tankari, M. B. Camara, B. Dakyo, and G. Lefebvre, "Use of ultracapacitors and batteries for efficient energy management in wind-diesel hybrid system,” IEEE Trans. Sustain. Energy, vol. 4, no. 2, pp. 414-424, Apr. 2013.

[13] C. Maftei, L. Moreira, and C. G. Soares, "Simulation of the dynamics of a marine diesel engine," J. Marine Eng. Technol., vol. 8, no. 3, pp. 29-43,2009.

[14] C. Hui, W. Peili, and Z. Jundong, "Modeling and simulation of working process of marine diesel engine with a comprehensive method,” Int. J. Comput. Inf. Syst. Ind. Manage. Appl., vol. 5, pp. 480-487, 2013.

[15] A. M. O. Haruni, A. Gargoom, M. E. Haque, and M. Negnevitsky, "Dynamic operation and control of a hybrid wind-diesel stand alone power systems," in Proc. 25th Annu. 
IEEE Appl. Power Electron. Conf. Expo., Palm Springs, CA, USA, pp. 162-169, Feb. 2010.

[16] A. A. G. Tomilson, "Frequency and voltage control of a high-penetration, no-storage wind-diesel system," M.Sc. thesis, Memorial Univ. Newfoundland, St. John's, Newfoundland, NF, Canada, Jul. 1998.

[17] H. He, R. Xiong, H. Guo, and S. Li, "Comparison study on the battery models used for the energy management of batteries in electric vehicles,” J. Energy Convers. Manage., vol. 64, pp. 113-121, 2012.

[18] M. Coleman, W. G. Hurley, and C. K. Lee, “An improved battery characterization method using a two-pulse load test," IEEE Trans. Energy Convers., vol. 23, no. 2, pp. 708-713, Jun. 2008.

[19] L. R. Chen, "Design of duty-varied voltage pulse charger for improving lion battery-charging response,” IEEE Trans. Ind. Electron., vol. 56, no. 2, pp. 480-487, Feb. 2009.

[20] M. B. Camara, H. Gualous, F. Gustin, A. Berthon, and B. Dakyo, "DC/DC converter design for supercapacitor and battery power management in hybrid vehicle applications-polynomial control strategy,” IEEE Trans. Ind. Electron., vol. 57, no. 2, pp. 587-597, Feb. 2010.

[21] C. T. Pan and Y. H. Liao, "Modeling and control of circulating currents for parallel three-phase boost rectifiers with different load sharing,” IEEE Trans. Ind. Electron., vol. 55, no. 7, pp. 2776-85, Jul. 2008.

[22] K.Kusakana andH. J.Vermaak, "Hybrid diesel generator battery systems for off-grid rural applications,” in Proc. IEEE Ind. Conf. Ind. Technol., Cape Town, South Africa, pp. 839-844, Feb. 2013.

[23] H. Ehsan, M. Bozorg, and M. Fotuhi-Firuzabad, "Stochastic capacity expansion planning of remote microgrids with wind farms and energy storage," IEEE Trans. Sustain. Energy, vol. 6, no. 2, pp. 491-498, Apr. 2015.

[24] R. Pena et al., "Wind-diesel generation using doubly fed induction machines,” IEEE Trans. Energy Convers., vol. 23, no. 1, pp. 202-214, Mar. 2008.

[25] W. Li, G. Jo'os, and J. B'elanger, "Real-time simulation of a wind turbine generator coupled with a battery supercapacitor energy storage system,” IEEE Trans. Ind. Electron., vol. 57, no. 4, pp. 1137-1145, Apr. 2010. 